The University of Maine

DigitalCommons@UMaine

Publications

Senator George J. Mitchell Center for Sustainability

Solutions

$12-2012$

\title{
Mercury Bioaccumulation in Wood Frogs Developing in Seasonal Pools
}

Cynthia Loftin

University of Maine - Orono

Aram J K Calhoun

University of Maine, Calhoun@maine.edu

Sarah J. Nelson

University of Maine

Adria A. Elskus

Co-Principal Investigator; University of Maine, Orono, adria.elskus@umit.maine.edu

Kevin Simon

Follow this and additional works at: https://digitalcommons.library.umaine.edu/ mitchellcenter_pubs

Part of the Forest Biology Commons

\section{Repository Citation}

Loftin, Cynthia; Calhoun, Aram J K; Nelson, Sarah J.; Elskus, Adria A.; and Simon, Kevin, "Mercury Bioaccumulation in Wood Frogs Developing in Seasonal Pools" (2012). Publications. 8.

https://digitalcommons.library.umaine.edu/mitchellcenter_pubs/8

This Article is brought to you for free and open access by DigitalCommons@UMaine. It has been accepted for inclusion in Publications by an authorized administrator of DigitalCommons@UMaine. For more information, please contact um.library.technical.services@maine.edu. 


\title{
Mercury Bioaccumulation in Wood Frogs Developing in Seasonal Pools
}

\author{
Author(s): Cynthia S. Loftin, Aram J.K. Calhoun, Sarah J. Nelson, Adria A. \\ Elskus and Kevin Simon \\ Source: Northeastern Naturalist, 19(4):579-600. \\ Published By: Eagle Hill Institute \\ DOI: http://dx.doi.org/10.1656/045.019.0404 \\ URL: http://www.bioone.org/doi/full/10.1656/045.019.0404
}

BioOne (www.bioone.org) is a nonprofit, online aggregation of core research in the biological, ecological, and environmental sciences. BioOne provides a sustainable online platform for over 170 journals and books published by nonprofit societies, associations, museums, institutions, and presses.

Your use of this PDF, the BioOne Web site, and all posted and associated content indicates your acceptance of BioOne's Terms of Use, available at www.bioone.org/page/ terms of use.

Usage of BioOne content is strictly limited to personal, educational, and non-commercial use. Commercial inquiries or rights and permissions requests should be directed to the individual publisher as copyright holder. 


\title{
Mercury Bioaccumulation in Wood Frogs Developing in Seasonal Pools
}

\author{
Cynthia S. Loftin ${ }^{1, *}$, Aram J.K. Calhoun ${ }^{2}$, Sarah J. Nelson ${ }^{3}$, Adria A. Elskus ${ }^{4}$, \\ and Kevin Simon ${ }^{5}$
}

\begin{abstract}
Seasonal woodland pools contribute significant biomass to terrestrial ecosystems through production of pool-breeding amphibians. The movement of amphibian metamorphs potentially transports toxins bioaccumulated during larval development in the natal pool into the surrounding terrestrial environment. We documented total mercury $(\mathrm{THg})$ in seasonal woodland pool water, sediment, litter, and Lithobates sylvaticus LeConte (Wood Frog) in Acadia National Park, ME. THg concentrations in pool water varied over the study season, increasing during April-June and remaining high in 2 of 4 pools upon October refill. Water in pools surrounded by softwoods had lower $\mathrm{pH}$, greater dissolved organic carbon, and greater $\mathrm{THg}$ concentrations than pools surrounded by hardwoods, with seasonal patterns in sediment $\mathrm{THg}$ but not litter $\mathrm{THg}$. THg increased rapidly from near or below detection in 1-2 week old embryos $(<0.2 \mathrm{ng} ; 0-0.49 \mathrm{ppb}$ wet weight) to $17.1-54.2 \mathrm{ppb}$ in tadpoles within 6 weeks; $7.2-42.0 \%$ of $\mathrm{THg}$ was methyl $\mathrm{Hg}$ in tadpoles near metamorphosis. Metamorphs emigrating from seasonal pools may transfer mercury into terrestrial food webs.
\end{abstract}

\section{Introduction}

Amphibians are among the most threatened vertebrates globally (Wake and Vredenburg 2008), and 7 of 10 amphibians breeding in seasonal woodland pools (also known as vernal or ephemeral pools) in the northeastern United States are of conservation concern (Mitchell et al. 2008). Seasonal pool-breeding amphibian populations in human-dominated landscapes suffer losses from degradation or destruction of breeding pools as well as fragmentation or loss of mature forests serving as summer refugia and hibernacula (Windmiller and Calhoun 2008). Chemical pollution, even in intact habitats, also can threaten the viability of amphibians in seasonal woodland pools, although this issue is not particularly well studied in the northeastern US (Boone and Pauli 2008). Amphibian egg and larval stages may be sensitive to environmental conditions, and exposure to pollutants during these stages can lead to developmental abnormalities, low hatchability,

${ }^{1}$ US Geological Survey, Maine Cooperative Fish and Wildlife Research Unit, 5755 Nutting Hall, University of Maine, Orono, ME 04469-5755. ${ }^{2}$ Department of Wildlife Ecology, 5755 Nutting Hall, University of Maine, Orono, ME 04469-5755. ${ }^{3}$ Senator George J. Mitchell Center for Environmental and Watershed Research, 5710 Norman Smith Hall, University of Maine, Orono, ME 04469-5710. ${ }^{4}$ US Geological Survey, Leetown Science Center, S.O. Conte Anadromous Fish Research Laboratory, Maine Field Office, 5751 Murray Hall, University of Maine, Orono, ME 04469-5751. ${ }^{5}$ School of Biology and Ecology, 5722 Deering Hall, University of Maine, Orono, ME 04469-5751. *Corresponding author - cynthia.loftin@maine.edu. 
delayed metamorphosis, and reduced metamorph and adult fitness in some species (Birge et al. 1979, Bridges et al. 2004, Britson and Threlkeld 1998, Terhivuo et al. 1984). Mercury ( $\mathrm{Hg}$ ) bioaccumulation has been documented in streamdwelling Eurycea bislineata Green (Two-lined Salamander) (Bank et al. 2005; Bergeron et al. 2010a, b) and more terrestrial species such as Anaxyrus americanus Holbrook (American Toad) and Plethodon cinereus Green (Red-backed Salamander) (Bergeron et al. 2010a, b). Similarly, Unrine et al. (2004, 2005) demonstrated in Lithobates sphenocephalus Cope (Southern Leopard Frog) that exposure in mesocoms to a diet with $\mathrm{Hg}$ concentrations ranging 54-3298 ng/g dry weight (reflecting in situ atmospheric contamination of their aquatic habitat) has the potential to affect amphibian development. Thresholds of these contaminants leading to impaired development and population level effects of reduced survival and reproductive success are unknown.

The amount of $\mathrm{Hg}$ deposition is large in the northeastern US when dry deposition in forested systems is accounted for (Johnson et al. 2007, Miller et al. 2005, Nelson et al. 2007, Rea et al. 1996). Wetlands in general are hotspots for conversion of $\mathrm{Hg}$ to the more biologically toxic methyl mercury $(\mathrm{MeHg})$. Per unit area, wetlands are estimated to contribute up to 80 times more $\mathrm{MeHg}$ to receiving water bodies than do upland areas (St. Louis et al. 1994). The optimal chemical environment in wetlands for microbiota responsible for $\mathrm{Hg}$ methylation includes abundant dissolved organic carbon (DOC), low $\mathrm{pH}$, low acid neutralizing capacity (ANC), and drying-wetting cycles (Benoit et al. 2002, Grigal 2003). For example, $\mathrm{MeHg}$ concentrations have been documented at levels potentially toxic to anuran larvae in seasonal wetlands (Carolina bays) in the southeastern US (Unrine et al. 2005). Similarly, seasonal woodland pools in the northeastern US may be hotspots for $\mathrm{Hg}$ methylation. In particular, many pools in Acadia National Park (ANP), ME, are characterized by low $\mathrm{pH}$ and relatively high DOC (Gahl and Calhoun 2010). In addition, ANP is an apparent hotspot for Hg deposition and accumulation in the environment, including bioaccumulation across trophic levels (Bank et al. 2005, 2007a, 2007b; Kahl et al. 2007, Longcore et al. 2007), in part owing to the interception of contaminated air masses within a landscape of $\approx 25 \%$ wetland area with a high prevalence of DOC-rich waters.

Seasonal woodland pools in ANP are the preferred breeding habitat for Lithobates sylvaticus LeConte (Wood Frog) (Cunningham et al. 2007, Kolozsvary 2003) and may be hotspots for $\mathrm{MeHg}$ production during key developmental stages of these animals. Wood Frogs undergo development from eggs to larvae during the spring and early summer, coincident with seasonal flushing of $\mathrm{Hg}$ from soils and litter with snowmelt into these small, relatively shallow wetlands (Nelson et al. 2008, Shanley et al. 2002). By mid- to late summer many pools dry, and only animals that have metamorphosed survive. This rapid morphogenesis occurs concurrently with dramatic changes in the drying pool environment, including rising water temperature, fluctuating $\mathrm{pH}$, declining oxygen, and increasing solute concentration (Colburn 2004 and references therein). These physical and chemical conditions may make amphibians in sea- 
sonal pools particularly susceptible to non-point source pollutants such as $\mathrm{Hg}$ (Unrine et al. 2004). These same pools refill with autumn rainfall (Calhoun and deMaynadier 2008, Colburn 2004) that could be enriched with $\mathrm{Hg}$, or could result in $\mathrm{Hg}$-enriched runoff from soils and litter.

Little is known about the presence and disposition of atmospherically deposited $\mathrm{Hg}$ in seasonal woodland pools in the Northeast or the relationship of $\mathrm{Hg}$ transformation with pool conditions and characteristics of the surrounding landscape. Conifers capture $\mathrm{Hg}$ more efficiently than deciduous species and also generally deliver more $\mathrm{Hg}$ in throughfall (Demers et al. 2007; Grigal et al. 2000; Johnson et al. 2007; Kolka et al. 1999; Rea et al. 1996, 2001), suggesting that pools in softwood dominated landscapes may receive more $\mathrm{Hg}$ in litterfall and total (wet + dry) deposition than pools embedded in hardwood forests. Mercury assimilation into the pool food web and its potential transport into surrounding terrestrial systems through Wood Frog emigration are undocumented. Such transport may be important given that amphibians can contribute significantly to terrestrial carbon reserves in southeastern (Gibbons et al. 2006, Unrine et al. 2007) and northern US seasonal wetlands (Berven 2009, Windmiller 1996). Negative implications for both metamorph survival (Unrine et al. 2004) and transport of $\mathrm{Hg}$ to the terrestrial environment may emerge as Wood Frog metamorphs with bioaccumulated $\mathrm{Hg}$ move from seasonal pools into the adjacent uplands.

Previous studies of $\mathrm{Hg}$ in ANP have documented occurrence of $\mathrm{Hg}$ in the environment (including relationships among forest type and deposition dynamics) and selected amphibian species in permanently flooded systems (e.g., streams, lakes) (Bank et al. 2005, 2007b). Our study targeted short-hydroperiod (e.g., inundated 3-9 weeks) amphibian breeding pools and examined relationships among pool chemical and physical characteristics (e.g., pool substrate type, size, hydroperiod, perimeter forest cover type, and burn history) and concentrations of total $\mathrm{Hg}$ ( THg) in developing Wood Frogs in these pools. We hypothesized that:

1) Developing Wood Frogs in ANP's seasonal pools contain detectable concentrations of $\mathrm{THg}$ that they have bioaccumulated in the natal pool.

2) THg concentrations in Wood Frog embryos and larvae are greatest in pools surrounded by softwood forests (compared to hardwood forests) because of high DOC and low $\mathrm{pH}$ in pool water and high $\mathrm{THg}$ concentrations in sediment, litter, and pool water.

3) Elevated concentrations of $\mathrm{THg}$ in the water persist throughout Wood Frog larval development, increasing the probability that $\mathrm{THg}$ is delivered into the adjacent terrestrial habitat with emigrating juvenile Wood Frogs.

\section{Methods}

\section{Study area}

We selected four small $(<0.10 \mathrm{ha})$, short-hydroperiod (i.e., pools likely to dry by mid-June; Table 1) seasonal woodland pools in ANP based on existing information about the Park's pool-breeding amphibian communities and hydrological 
data (B. Connery, National Park Service, ANP, Bar Harbor, ME, pers. comm.; Cunningham et al. 2007; Gahl and Calhoun 2010; Kolozsvary 2003) and Hg litterfall, throughfall, and snow chemistry data (Johnson et al. 2007, Nelson et al. 2008, Sheehan et al. 2006). ANP covers approximately half (122 $\left.\mathrm{km}^{2}\right)$ of Mount Desert Island (MDI) and is at the southern limit of the spruce-fir/northern hardwoods zone (Westfeld et al. 1956) in the Fundy Coastal and Interior section of the Laurentian Mixed Forest (Bailey et al. 1994). Uplands are dominated by thin, granitic soils (Chapman 1970, Gilman et al. 1988), whereas organic soils are common in wetlands (Calhoun et al. 1994). Palustrine wetlands are concentrated in the eastern half of MDI, while ponds and lakes cover $4 \%$ of the island. A fire ignited in Bar Harbor in 1947 burned coniferous forests on the east side of the Park. Post-fire forests are dominated by deciduous species (Betula spp. [birch], Acer spp. [maple], Populus spp. [aspen]), while conifers (Picea spp. [spruce], Tsuga canadensis (L.) Carr [Eastern Hemlock], Abies balsamea (L.) P. Mill [Balsam Fir], Pinus spp. [pine]) dominate the unburned regions of the Park (Schauffler et al. 2007). Two of

Table 1. Characteristics of seasonal pools sampled during April-October 2008, Acadia National Park, ME.

Characteristic

Pool type

Forest vegetation $^{\mathrm{A}}$

Landscape burn history

Within-pool litter composition ${ }^{\mathrm{B}}$; decay condition
B 1

Upland
depression

Red Maple, Gray Birch, Red Oak

\section{Burned} Birch, maple, sedge spp. leaves; moderate

Sediment $\%$ organic matter ${ }^{\mathrm{C}}$

Pool $\mathrm{pH}$ range

Dissolved organic carbon $(\mathrm{mg} / \mathrm{L})$

Acid neutralizing capacity $(\mu \mathrm{eq} / \mathrm{L})$

Dissolved aluminum ( $\mu \mathrm{g} / \mathrm{L})$

Sulfate $(\mu \mathrm{eq} / \mathrm{L})$

Chloride $(\mu \mathrm{eq} / \mathrm{L})$

Calcium $(\mathrm{mg} / \mathrm{L})$

$54.2 \pm 2.67$
$5.56-5.93$
$1.6-12.0$
$112-254$
$40-165$
$58-90$
$81-99$
$4.08-6.75$

$53.8 \pm 17.1$
$4.41-4.93$
$1.2-3.7$
$1.29-2.61$
$114-157$
$37-49$
$73-90$
$0.26-0.31$

$4.8 \pm 1.2$

$5.57-6.11$

$1.8-7.0$

$57.6-130$

$13.9-157$

29-52

107-185

$1.11-1.97$

$0.26-0.3$
Gray Birch, Tamarack,

Gray Birch

Unburned gravel, sand minor
U2

Forested

wetland

complex

Red Spruce,

Black Spruce,

Tamarack,

White Pine,

Red Maple

Unburned

Sphagnum,

spruce

needles,

sedge spp.;

peat

(advanced

decay)

$81.3 \pm 3.0$

4.03-4.33

$12.8-39.8$

117-42.1

207-806

27-62

$83-138$

$0.22-0.51$

${ }^{\text {A}}$ Quercus rubra L. (Red Oak), Acer rubrum L. (Red Maple), Betula populifolia Marsh (Gray Birch), Picea rubens Sarg. (Red Spruce), P. mariana (P. Mill) B.S.P. (Black Spruce), P. glauca (Moench) Voss (White Spruce), Pinus strobus L. (White Pine), Larix laricina (Du Roi) K. Koch (Tamarack).

${ }^{\mathrm{B}}$ Carex spp. L. (sedge spp.), Sphagnum (sphagnum).

${ }^{\mathrm{C}} n=3$, mean $\pm \mathrm{SD} ; n=2$ for $\mathrm{U} 2$. 
our study pools (B1, B2) occur in areas burned in 1947, and two study pools (U1, U2) were located in the unburned region, providing a contrast in forest cover type (deciduous vs. coniferous) and burn history.

\section{Sample collection}

The first sample collection from three pools (B1, U1, U2) was on 7 April 2008, whereas pool B2 was first sampled on 11 April. All pools dried by late June. Rainfall during 26 September-2 October refilled pools to water levels similar to those recorded in mid-April. Our final collection of environmental samples for THg and chemical analyses was on 2 October 2008, after the first pool-filling rain following mid-summer (June) drying.

We sampled pool water (within $10 \mathrm{~cm}$ of water surface), litter, and sediment (top $6 \mathrm{~cm}$ ) soon after ice-out to establish initial chemical conditions. We collected one 500-mL pool-water sample in HDPE bottles for major ion and DOC analysis (after rinsing the collection bottle 3 times with pool water) and one $100-\mathrm{mL}$ pool-water sample in a syringe for closed-cell $\mathrm{pH}$ determination. Water sampling was conducted following methods used in US Environmental Protection Agency (US EPA) long-term monitoring programs at ANP (Kahl et al. 2004). We collected 5 grab samples of wetland (water-saturated) litter and combined them into one sample to represent each pool's litter. Similarly, we collected upland litter within $3 \mathrm{~m}$ of the pool perimeter. We collected two sediment samples with a 5-cm-diameter pre-cleaned plastic tube pushed into the pool bottom and removed with the sediment plug retained intact. We extruded the sediment in $2-\mathrm{cm}$ increments, retaining the water above the first $2 \mathrm{~cm}$ with that sample given the flocculent nature of the substrate surface. Two sediment samples from each collection were analyzed individually for $\mathrm{THg}$ and reported as a mean for that collection date and pool. Additional sediment samples $(n=3)$ were collected with these methods from each pool on 14 September 2010 for determination of ash-free dry mass in the top $2 \mathrm{~cm}$. Samples to be analyzed for $\mathrm{THg}$ or $\mathrm{MeHg}$ were placed on dry ice immediately after collection and frozen to $-80{ }^{\circ} \mathrm{C}$ within four hours until analyzed. Water samples for general chemical and $\mathrm{THg}$ analysis were stored in an ice-filled cooler and filtered, preserved, and refrigerated within 4 hours of collection.

Wood Frog embryos and larvae were collected from each pool on several dates. The animals were placed in individual plastic containers filled with pool water until returned to the lab, where they were photographed, evaluated for Gosner stage (GS; Gosner 1960) and abnormalities (with a stereomicroscope at 10X), euthanized with tricane methanesulfonate (MS222), and frozen. We collected one developing Wood Frog embryo from up to 8 separate egg masses (only one embryo removed from each egg mass) in each pool on each visit. We first collected embryos on 18 April in B1 ( $n=8$; GS 10-17), B2 $(n=8$; GS 9), and U1 ( $n=8$; GS 7-13) and on 25 April in U2 ( $n=8$; GS 3-16), and we collected a second sample of embryos from U1 on 25 April $(n=7$; GS 18-23). Our subsequent collections were timed to capture larvae in late developmental stages 
but just before pools dried. Tadpoles were collected from U1 on 16 May $(n=8$ tadpoles; GS 26), from U1 ( $n=8$; GS 24-33) and U2 ( $n=8$; GS 29) on 6 June, and from B1 ( $n=8$; GS 34-37) on 19 June; pool B2 dried before tadpoles could be collected. No juveniles were collected, because all pools dried before tadpoles completed metamorphosis.

We strictly adhered to clean $\mathrm{Hg}$-collection protocols to prevent $\mathrm{Hg}$ contamination of field samples (see Nelson et al. 2008). Powder-free gloves were used when collecting all sample types, and sampling equipment and sample containers were teflon, glass, stainless steel, or plastic that had been tested for $\mathrm{Hg}$ prior to field use and transported to the field in clean plastic bags. All sample-collection equipment was acid washed between sampling trips, and sediment sample-collection equipment was rinsed with ultrapure water between samples. Samples were doublebagged in the field to minimize contamination.

\section{Chemical analyses}

Water chemistry analyses ( $\mathrm{THg}, \mathrm{Ca}, \mathrm{Mg}, \mathrm{K}, \mathrm{Na}, \mathrm{Al}, \mathrm{Cl}, \mathrm{NO}_{3}, \mathrm{SO}_{4}, \mathrm{DOC}$, closed-cell pH, ANC, specific conductance) were conducted at the University of Maine Sawyer Environmental Chemistry Research Lab (UMSECRL), Orono, ME (methods detailed in Kahl et al. 2007 and Navratil et al. 2010). Analytical methods for determination of analytes in liquid samples were as follows: Ca, $\mathrm{Mg}, \mathrm{Na}, \mathrm{K}$, and total $\mathrm{Al}$ were measured by inductively coupled plasma optical emission spectroscopy (ICP). Sulfate $\left(\mathrm{SO}_{4}\right), \mathrm{NO}_{3}$, and $\mathrm{Cl}$ were measured by ion chromatography. ANC was determined by Gran titration, and closed-system $\mathrm{pH}$ was measured by collecting samples underwater with a syringe and injecting samples directly into an electrode cell (Hillman et al. 1986). Closed-system $\mathrm{pH}$, which is not exposed to air with ambient $\mathrm{CO}_{2}$ concentrations, reflects the in-situ $\mathrm{pH}$ experienced by biota within the waterbody. DOC was quantified with persulfate oxidation and infrared detection. Determination of ash-free dry mass followed ASTM D 2974 (2007).

Water samples were preserved with $1 \% \mathrm{v} / \mathrm{v} 0.2 \mathrm{~N}$ bromine monochloride, and analyzed for $\mathrm{THg}$ by dual amalgamation, cold vapor atomic fluorescence spectrometry (EPA method 1631E) using a Tekran 2600 MDS in a clean room (US EPA 2002). The method reporting limit (MRL) was $0.5 \mathrm{ng} / \mathrm{L}$, and the method detection limit (MDL) was $0.04 \mathrm{ng} / \mathrm{L}$. Sediment, litter, and Wood Frog samples were stored frozen at $-20{ }^{\circ} \mathrm{C}$, and $\mathrm{THg}$ in sediment, litter, and Wood Frogs (wet weight) was analyzed for $\mathrm{THg}$ by thermal decomposition, amalgamation, atomic absorption spectrometry (EPA method 7473) using a Milestone Direct Mercury Analyzer (DMA-80) with EPA method 7473 at the UMSECRL (US EPA 1994). The MRL was $1 \mathrm{ng}$ absolute mass of $\mathrm{Hg}$, and the MDL was $0.032 \mathrm{ng}$. The MRL and MDL for the DMA are given in mass rather than concentration in calibration, and concentration limits are determined by mass of sample analyzed. $\mathrm{THg}$ and $\mathrm{MeHg}$ were analyzed in a subset of tadpoles by Brooks Rand Lab (Brooks Rand Lab, Seattle, WA) using EPA Method 1631 Appendix (for THg) and EPA Method 1630 modification (for MeHg) (US EPA 2002). The MRL was $3.00 \mathrm{ng} / \mathrm{g}(\mathrm{MeHg}$ ) and $1.00 \mathrm{ng} / \mathrm{g}$ ( $\mathrm{THg}$ ), and the MDL was $1.00 \mathrm{ng} / \mathrm{g}(\mathrm{MeHg})$ and $0.40 \mathrm{ng} / \mathrm{g}(\mathrm{THg})$. All values are reported on a wet-weight basis, except for upland litter, which was air dried. 


\section{Data analyses}

Our analyses focused on identifying spatio-temporal patterns among pools in water chemistry and $\mathrm{THg}$ concentrations in the litter, sediment, water, and developing Wood Frogs. We identified correlations between THg in water, upland litter, wetland litter, wetland sediment, water chemistry analytes, and Wood Frog THg with Spearman rank-order correlations. We compared sediment, water, upland and wetland litter, water chemistry analytes, and Wood Frog THg among pools with Kruskal-Wallis tests, a non-parametric analysis analogous to a oneway analysis of variance. We used an $\alpha \leq 0.05$ to determine significance in these analyses. Statistical analyses were conducted in R version 2.11.1 (The R Foundation for Statistical Computing).

\section{Results}

Both spatial and temporal differences occurred in pool water chemistry. Pool-water DOC concentrations differed (Kruskal-Wallis Chi Square = 10.0425 , $\mathrm{df}=3, P=0.0182)$ among pools, gradually increased during AprilOctober in all pools (with slight decrease in B1 in October), and consistently were greatest in U2 (Fig. 1). The $\mathrm{pH}$ of pool water differed (Kruskal-Wallis

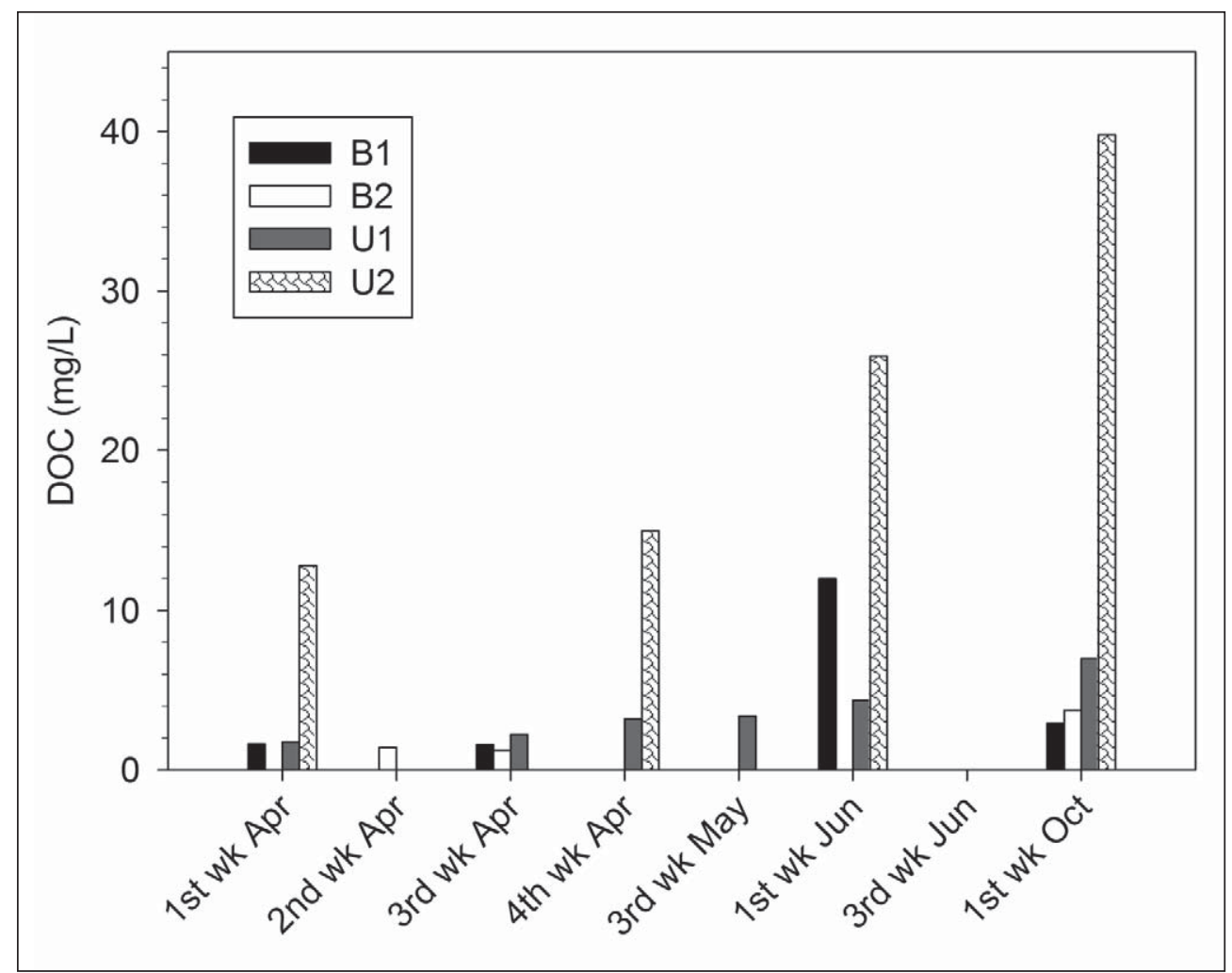

Figure 1. Dissolved organic carbon (DOC; $\mathrm{mg} / \mathrm{L}$ ) measured in water samples collected during April-October 2008 in seasonal woodland pools in Acadia National Park, ME. B2 dried by the first week in June, U1 and U2 dried by the third week in June, and B1 dried by early July. Each bar represents 1 sample. 


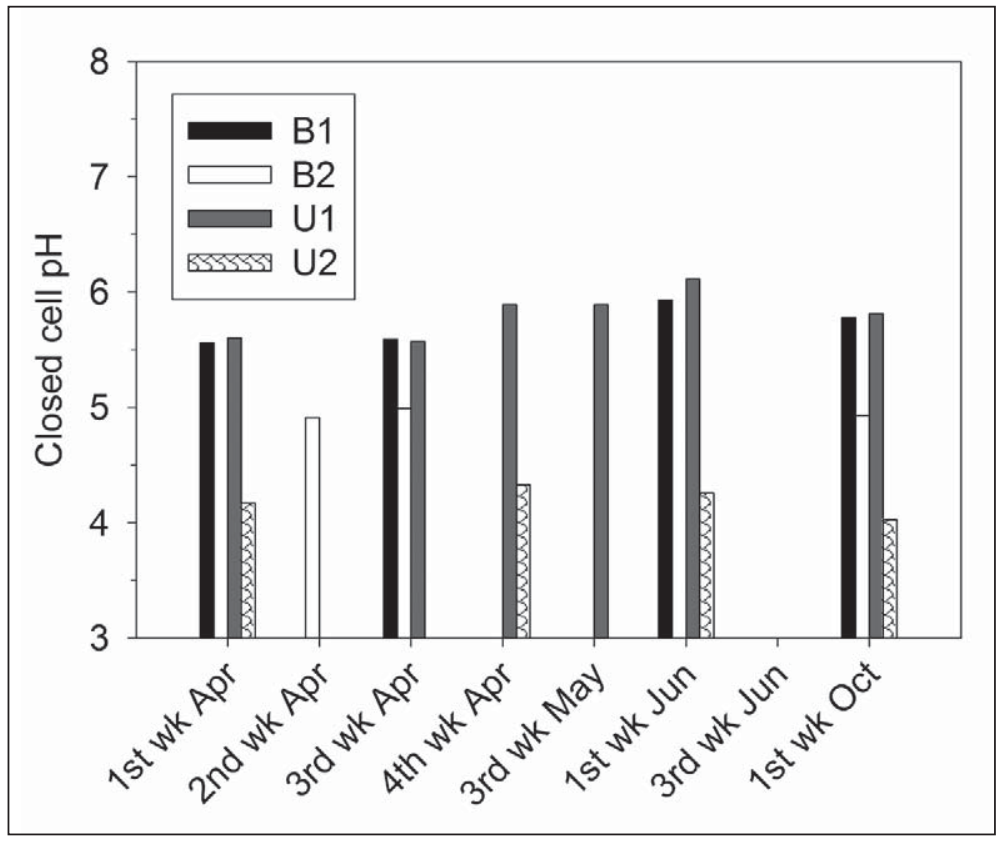

Figure 2. Closedcell $\mathrm{pH}$ measured in water samples collected during April-October 2008 in seasonal woodland pools in Acadia National Park, ME. B2 dried by the first week in June, U1 and U2 dried by the third week in June, and B1 dried by early July. Each bar represents 1 sample.

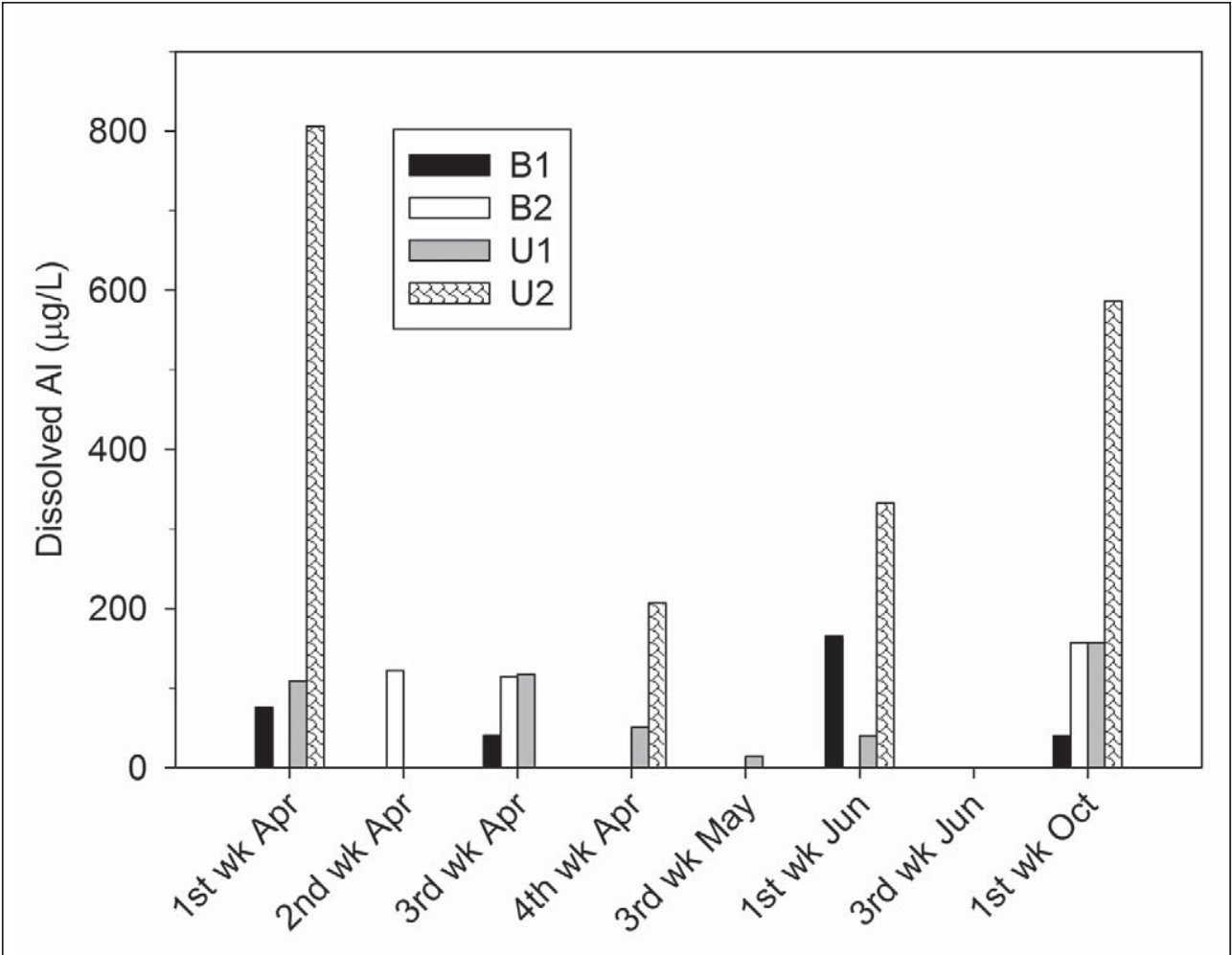

Figure 3. Dissolved aluminum ( $\mu \mathrm{g} / \mathrm{L})$ measured in water samples collected during AprilOctober 2008 in seasonal woodland pools in Acadia National Park, ME. B2 dried by the first week in June, U1 and U2 dried by the third week in June, and B1 dried by early July. Each bar represents 1 sample. 
Chi Square $=12.7673$, df $=3, P=0.0052)$ among pools and consistently was lowest in U2 (Fig. 2). Dissolved aluminum (Al) concentrations differed (Kruskal-Wallis Chi Square $=9.932, \mathrm{df}=3, P=0.0192$ ) among pools and were greater in U2 than the other pools throughout the sample period (Fig. 3), with the greatest concentration $(806 \mu \mathrm{g} / \mathrm{L})$ measured in water collected from $\mathrm{U} 2$ while it was mostly ice-covered ( 7 April). The least dissolved Al concentration $(207 \mu \mathrm{g} / \mathrm{L})$ in $\mathrm{U} 2$ was measured during the first ice-free collection date (25 April). Pool-water DOC and dissolved aluminum concentration were correlated (Spearman rank-order correlation $r_{\text {adj }}=0.62, P=0.0081, n=17$ ). Concentrations of THg in pool water differed among pools (Kruskal-Wallis Chi Square $=9.6384, \mathrm{df}=3, P=0.0219$ ), increased through the season (Fig. 4), were correlated with pool-water DOC (Spearman rank-order correlation $r_{\text {adj }}=0.86, P=$ $0.0001, n=17)$, and were greater in pools in the unburned, softwood-dominated setting (U1, U2) than in the burned, deciduous setting (B1, B2). Concentrations of THg in water collected from U2 in October (17.4 ng/L) exceeded all records of THg measured in Acadia's streams (maxima for previous studies were 6.5$8.0 \mathrm{ng} / \mathrm{L}$; Nelson et al. 2007, Peckenham et al. 2007).

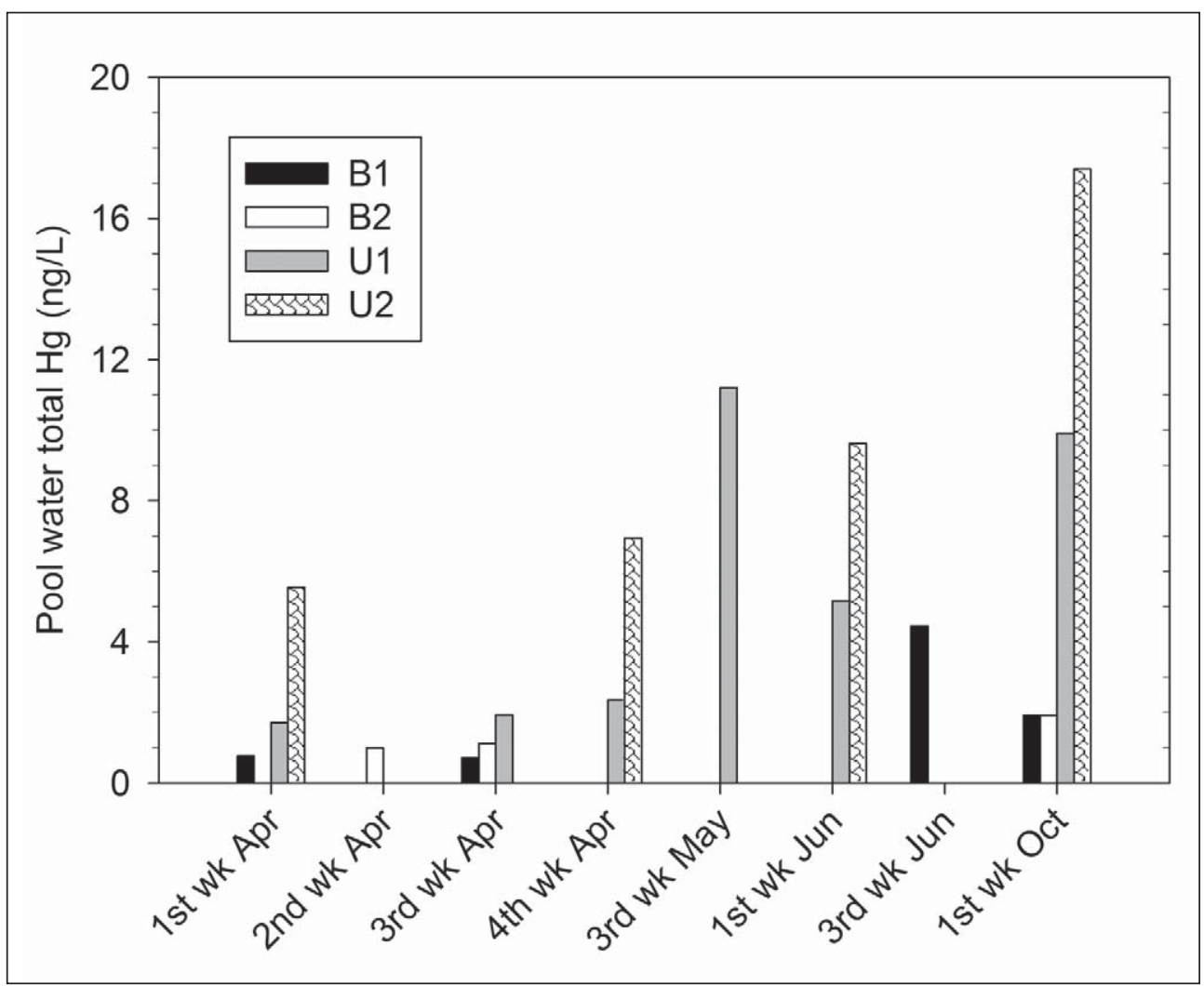

Figure 4. Total Hg (ng/L) measured in water samples collected during April-October 2008 in seasonal woodland pools in Acadia National Park, ME. B2 dried by the first week in June, U1 and U2 dried by the third week in June, and B1 dried by early July. Each bar represents 1 sample. 


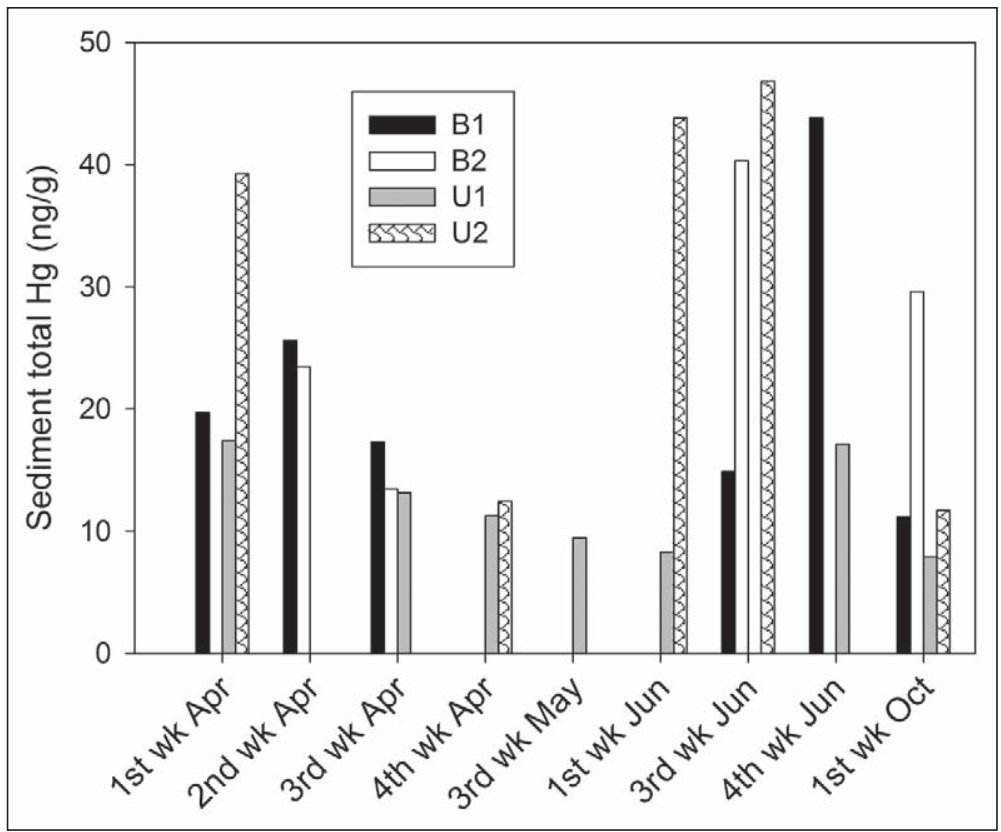

Figure 5. Total $\mathrm{Hg}$ (ng/g, wet weight) measured in 0-2 $\mathrm{cm}$ deep sediment samples collected during April-October 2008 in seasonal woodland pools in Acadia National Park, ME. Each bar represents mean of 2 samples. B2 dried by the first week in June, U1 and U2 dried by the third week in June, and B1 dried by early July.

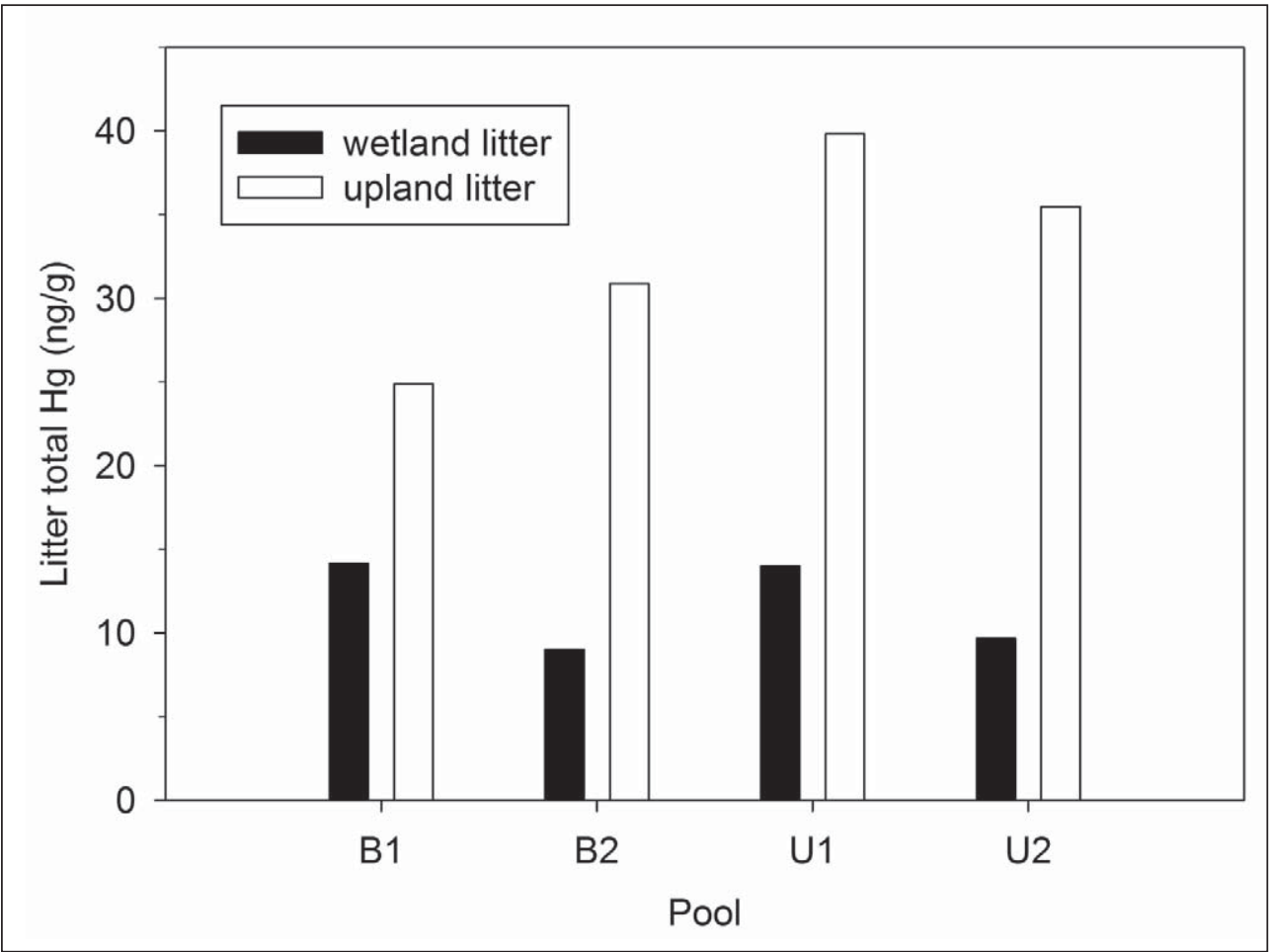

Figure 6. Total $\mathrm{Hg}(\mathrm{ng} / \mathrm{g})$ measured in litter samples collected within seasonal pools and $3 \mathrm{~m}$ from the pool edge during April-October 2008 in Acadia National Park, ME. Litter subsamples were extracted from composited grab samples; coniferous and deciduous litter were analyzed separately and are reported as means of combined subsamples collected within the pool (wet weight) or upland (dry weight) across the study period. 
Sediment THg concentration (mean for each pool and collection date) ranged from 7.9 to $46.8 \mathrm{ng} / \mathrm{g}$ among sites, although differences among sites were not significant, and these concentrations tended to be greatest late in June (Fig. 5). We detected no apparent associations between sediment THg (Fig. 5), landscape burn history, or pool setting in the landscape; however, patterns in sediment $\mathrm{THg}$ reflected sediment percent organic matter (Table 1). THg concentrations in wetland litter were not significantly different among pools (Fig. 6); however, THg in $\mathrm{U} 1$ and $\mathrm{U} 2$ upland litter was 25\% greater than THg in upland litter from B1 and B2. THg concentrations in wetland litter were roughly half those in upland litter, a difference potentially reflecting our analysis approach (wet-analyzed wetland litter versus dry-analyzed upland litter) rather than true differences between $\mathrm{THg}$ concentrations in wetland and upland litter.

THg measured in Wood Frog embryos $(n=15)$ in GS 3-21 were below detection limits $(<0.2 \mathrm{ng} ; 0-0.49 \mathrm{ppb}$; all concentrations in Wood Frogs reported as ppb wet weight); however, concentrations rapidly increased to 15.2-54.2 ppb in tadpoles $(n=25)$ within $2-4$ weeks post-hatch (GS 24-36) (Fig. 7). THg concentrations in Wood Frogs were correlated with THg in pool water (Spearman rank-order correlation $r_{\text {adj }}=0.74, P=0.0366, n=8$ ). Pool B2 dried before embryos hatched, and the remaining 3 pools dried before tadpoles metamorphosed. Final THg concentrations in Wood Frog tadpoles collected

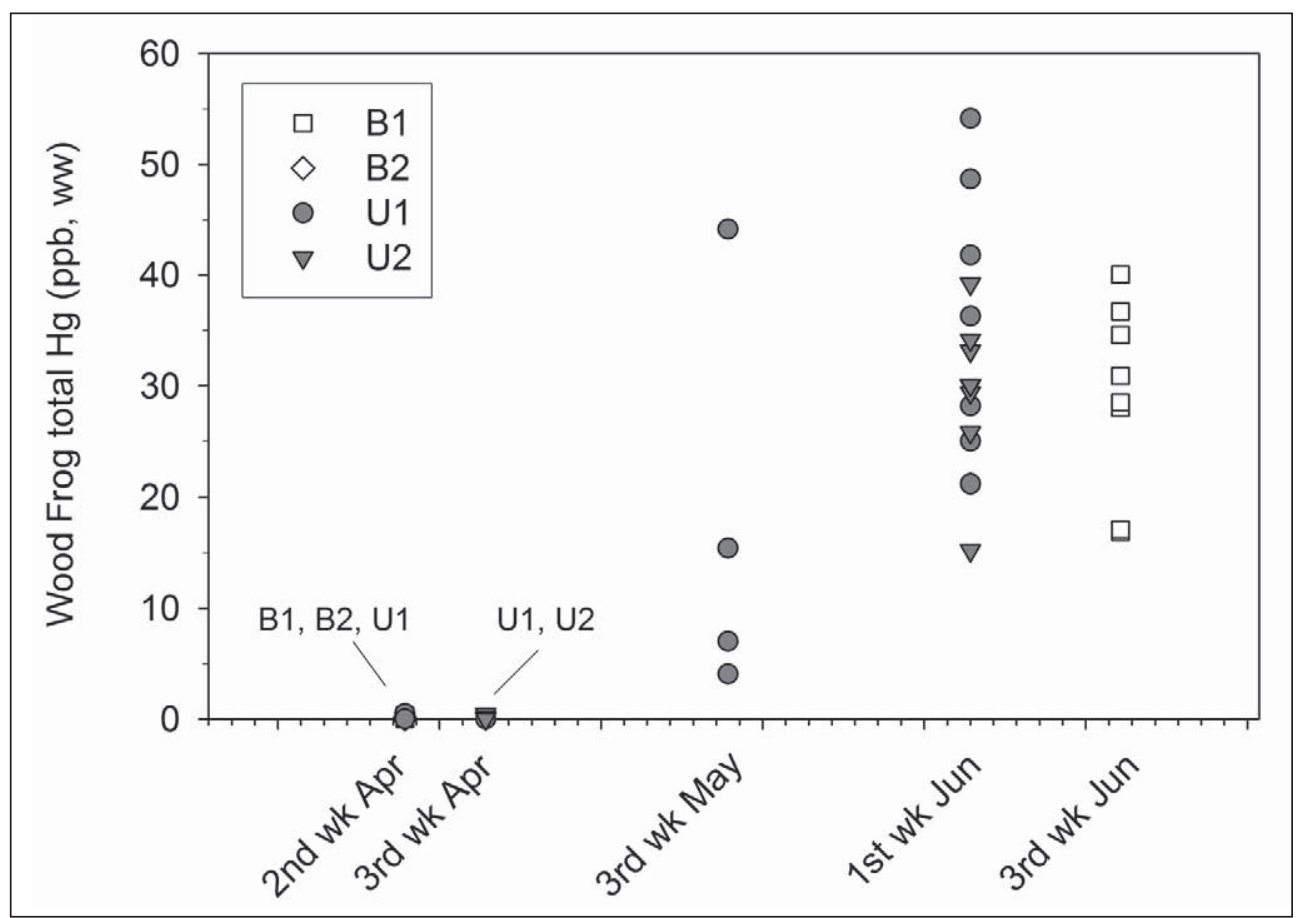

Figure 7. Total Hg (ng/g, wet weight) measured in Wood Frog embryos and tadpoles collected during April-October 2008 in seasonal woodland pools in Acadia National Park, ME. Symbols represent individual embryos or larvae. B2 dried by the first week in June, $\mathrm{U} 1$ and $\mathrm{U} 2$ dried by the third week in June, and B1 dried by early July. 
when pools were nearly dry were similar among pools (Fig. 7), and ratio of $\mathrm{MeHg}$ to $\mathrm{THg}$ concentrations at pool drying ranged from $7-42 \%$ in pools surrounded by softwoods (U1,U2; 4 tadpoles) and 36\% and 37\% in pools in hardwood settings (B1, B2; 2 tadpoles).

\section{Discussion}

\section{Wood Frog development}

Our findings support our hypotheses that (a) developing Wood Frogs in ANP's seasonal pools bioaccumulate detectable concentrations of THg in the natal pool, and (b) elevated concentrations of $\mathrm{THg}$ in the water would persist throughout Wood Frog larval development, increasing the probability that THg is delivered into the adjacent terrestrial habitat with emigrating juvenile Wood Frogs. Wood Frogs oviposited in all study pools; however, only 3 of 4 pools retained water through embryonic development. Wood Frog tadpoles in those 3 remaining study ponds were within 12 weeks of completing metamorphosis when the pools dried. Although there is some support for our hypothesis that THg concentrations in Wood Frog larvae would track patterns of THg concentrations in the pool water that reflect the forest composition in the surrounding landscape, this result should be considered cautiously, owing to the small number of pools sampled in our study. Our study pools are in landscapes with different burn histories and forest compositions, and we were not able to apply a study design that replicated these conditions in addition to that of the gradient of long to short hydroperiod. We also repeatedly sampled the same pools to capture $\mathrm{Hg}$ temporal dynamics, creating pseudoreplication in our dataset. These factors are caveats in interpretation of our results (i.e., there is limited separation of variables describing pool type), yet our study suggests compelling patterns worth additional study.

Concentrations of THg in Wood Frogs were at or below detection limits $(<0.02$ ng wet wt, which translated to $<0.5 \mathrm{ppb}$ ) from egg laying to final embryo collections (GS 21), indicating that maternal transfer is absent or minimal in the study area. This finding contrasts with that of Bergeron et al. (2010a), who reported maternal transfer of $\mathrm{Hg}$ in American Toads breeding in Virginia ponds contaminated with Hg. In our Wood Frog tadpoles, however, concentrations of THg were similar to those in adults and tadpoles of other frog species. In our study, THg had accumulated to $44.1 \mathrm{ppb}$ in weeks-old Wood Frog tadpoles collected from U2 by the third week in May (GS 26), and THg ranged from 28.2-54.2 ppb across our seasonal pools by the first week in June (GS 24-36). These Hg concentrations overlap ranges of concentrations reported in 2-3 year old $L$. clamitans Latreille in Sonnini de Manoncourt and Latreille (Green Frog) (30-110 ppb) and L. catesbeiana Shaw (American Bullfrog) (42-75 ppb) tadpoles collected from permanently flooded ponds in nearby watersheds in ANP (Bank et al. 2005).

We analyzed MeHg and THg in only a subset $(n=6)$ of our collected Wood Frog larvae. MeHg comprised 6.6-42.0\% of THg in Wood Frog tadpoles collected 
when pools were nearly dry in our study and 7.6-40.0\% of THg in Green Frog and Bullfrog tadpoles collected in permanent water bodies in nearby watersheds (Bank et al. 2007b). We did not detect any malformations or indications that the developing Wood Frog tadpoles were physically compromised by the $\mathrm{Hg}$ they had accumulated in their tissues, and we do not know if these $\mathrm{Hg}$ body burdens compromise Wood Frog fitness upon metamorphosis.

Wood Frog tadpoles are opportunistic predators and will consume aquatic invertebrates as well as embryos and larvae of sympatric amphibian species during this period of rapid growth within seasonal pools (Baldwin and Calhoun 2002, Petranka et al. 1994, Sours et al. 2007). Although pool water remained clear through June, and algal accumulation appeared minimal, bacterial and fungal biofilms growing on sediments and leaves may have contained $\mathrm{Hg}$ and been grazed by the Wood Frog tadpoles (Unrine et al. 2005, 2007), which may, in addition to $\mathrm{THg}$ in pool water, explain the concentrations of $\mathrm{THg}$ detected in their tissues.

\section{Total mercury concentrations in the pool environment}

$\mathrm{Hg}$ concentrations at any location are affected by landscape characteristics and atmospheric conditions spanning local to regional scales. Because of their small size and forested character, seasonal woodland pools may receive elevated inputs of dry deposition initially captured by the forest canopy compared with, for example, lakes with large surface areas without forest canopy. In addition to throughfall from the forest canopy, $\mathrm{Hg}$ is delivered directly into terrestrial systems through overland flow, precipitation, and litterfall (Grigal 2002). The relationships we report between $\mathrm{THg}$ concentrations and environmental conditions at our study sites may reflect the variety of conditions within the study pools and the surrounding landscapes in which they are embedded. Owing to our small sample size, we cannot be certain that observed differences in THg concentrations among pools are determined primarily by landscapescale patterns or local conditions such as observed in wetland ecosystems in Nova Scotia, Canada (Rencz et al. 2003) and in southeastern US Carolina bays (Unrine et al. 2005).

Conifers capture $\mathrm{Hg}$ more efficiently than deciduous species and also generally deliver more $\mathrm{Hg}$ in throughfall (Demers et al. 2007, Johnson et al. 2007), and as expected we found that pools embedded in softwood-dominated (coniferous) landscapes (U1, U2) contained greater concentrations of $\mathrm{THg}$ in pool water than pools embedded in hardwood landscapes (B1, B2). The reduced $\mathrm{Hg}$ concentrations in B1 and B2 sediments also may reflect reemission and mobilization of $\mathrm{Hg}$ in the 1947 fire that burned the watersheds of these pools (Amirbahman et al. 2004). Mean THg concentration was $7.18 \pm 1.57 \mathrm{ng} / \mathrm{L}$ (mean $\pm \mathrm{SD} ; n=10$ ) in water from pools embedded in the softwood-dominated landscape (U1, U2) and $1.69 \pm 1.31 \mathrm{ng} / \mathrm{L}(n=7)$ at pools embedded in the hardwood-dominated landscape (B1, B2). This result agrees with previous studies that estimated $\mathrm{Hg}$ deposition of throughfall at softwood forested sites 
(resembling U1 and U2) in ANP as $34.3 \pm 22.2 \mathrm{ng} / \mathrm{m}^{2} /$ day, whereas, deposition of $\mathrm{Hg}$ in hardwood sites (near B1 and B2) that burned in 1947 was about 18\% less $\left(28.1 \pm 19.5 \mathrm{ng} / \mathrm{m}^{2} /\right.$ day) (Johnson et al. 2007).

\section{Litterfall}

Litterfall is a major pathway for distributing $\mathrm{Hg}$ to the forest floor and throughout watersheds (Grigal 2002). Hg accumulated on deciduous leaves during the growing season is deposited in greater mass in less time than from conifer leaves, especially during autumn dehiscence when $\mathrm{Hg}$ concentrations in leaves are at their maximum (Grigal et al. 2000, Lindberg 1996, Rea et al. 1996). Seasonal woodland pools embedded in a forested landscape capture this litterfall annually, often coincident with autumn storms that refill these wetlands. We expected THg in coniferous litter to be greater than in deciduous litter, as previously reported in ANP by Sheehan et al. (2006). We found this expected forest or landscape composition-related difference in $\mathrm{Hg}$ concentrations of upland litter but not of wetland litter. THg concentrations in upland litter were slightly greater in the pools (U1, U2) in the conifer-dominated, unburned area of ANP than in upland litter from pools (B1, B2) in the burned area. THg concentrations in deciduous and coniferous litter collected within our study pools, however, generally were similar among pools (Fig. 6). THg estimates in our wetland litter samples are wet weights, whereas $\mathrm{THg}$ estimates in our upland samples are dry weights, restricting our comparisons to those among pools (rather than between upland and wetland litter), and reflecting the wetland litter-associated $\mathrm{THg}$ to which a tadpole would be exposed.

\section{Sediment}

Contrary to our expectation, pool sediment $\mathrm{THg}$ concentrations did not reflect watershed burn history. We expected that THg concentrations in sediments collected from unburned sites U1 and U2 would exceed those collected in burned sites $\mathrm{B} 1$ and $\mathrm{B} 2$ owing to release of $\mathrm{Hg}$ with burning in the contributing watersheds of B1 and B2, similar to observed effects of the 1947 fire on ANP soils (Amirbahman et al. 2004). Instead, the lowest THg concentrations were found in U1 sediments, which were a sand-gravel mixture. It may be that the differences we observed in sediment THg among pools is owing to within-pool sediment type and percent organic matter. Sediments collected from the other pools (U2, B1, B2) contained less sand and gravel and more organic matter, were predominantly decaying leaves, and consistently contained greater $\mathrm{THg}$ concentrations than U1 (Fig. 5, Table 1).

Prior to refill, pool sediments likely incorporate $\mathrm{Hg}$ from decomposing litter, as well as from $\mathrm{Hg}$ translocated to the litter from the underlying soil (Demers et al. 2007). Concentrations of $\mathrm{THg}$ are greatest in the upper 1-2 cm of upland soil (Schluter et al. 1995) and in water in contact with upper soil horizons, where concentrations of DOC also are greatest (Fleck 1999, Grigal 2002, Shanley et al. 2005). Episodic release of $\mathrm{Hg}$ in high-flow events is 
correlated with releases of particulate organic carbon from soils, particularly the O-horizon, which contains most of the soil Hg burden (Grigal 2002, Hurley et al. 1998, Shanley et al. 2005).

We observed an increase in sediment THg in all pools during the June drawdown, then a decrease in sediment THg in all pools upon refill in October (Fig. 5). When inundated, topographic depressions with seasonally wet soils such as seasonal woodland pools could provide conditions leading to significant $\mathrm{Hg}$ reduction and methylation owing to increased sulfate concentrations and activity of sulfate-reducing bacteria (Grigal 2003). Our observed decrease in sediment $\mathrm{THg}$ at pool re-fill in October may reflect dilution of $\mathrm{Hg}$ in pool sediments by storm run-off. Although pool B2 sediment THg concentration decreased upon refill in October, THg concentration in this pool remained greater than that at April ice-out (Fig. 5); this pool had the earliest dry date of the sampled pools. Future research should include speciation of sediment $\mathrm{Hg}$ and focus on dynamics of sulfate-reducing bacteria, largely responsible for $\mathrm{Hg}$ methylation, in pool sediments as pools fill and dry.

\section{Temporal dynamics of pool chemical environments}

We expected peak THg concentrations in pool water with spring snowmelt; however, we found maximum THg concentrations occurred during May, June, or October (Fig. 4). We attribute this pattern to $\mathrm{Hg}$ mobilized from the pool sediments with drying and rewetting and with throughfall and litterfall inputs occurring over several weeks or months of summer dry deposition. Terrestrial systems distribute atmospherically deposited $\mathrm{Hg}$ into embedded aquatic systems such as woodland pools via throughfall and runoff (Krabbenhoft et al. 1995, Lee et al. 1994, Lorey and Driscoll 1999) that carries Hg associated with dissolved and particulate organic material (Grigal 2003, Rencz et al. 2003, Schuster et al. 2008). During spring snowmelt, $\mathrm{Hg}$ carried with dissolved and particulate organic matter from accumulated litter and the soil organic layer is re-suspended in meltwater infiltrating the upper soil horizons with thawing (Hurley et al. 1998, Nelson et al. 2008, Shanley et al. 2002). As the snowpack melts from below, the meltwater combines with $\mathrm{Hg}$ released from the melting soil frost layer, resulting in a peak release of $\mathrm{Hg}$ to streams and other water bodies immediately preceding peak snowmelt discharge (Schuster et al. 2008) that often occurs with early spring rain. Scherbatskoy et al. (1998) reported that nearly half the annual $\mathrm{Hg}$ flux in a Vermont stream occurred in a single day of peak snowmelt. Both THg (Fig. 4) and DOC (Fig. 1) concentrations measured in our study's pool water generally increased during April-June, suggesting concentration of solutes with dry-down. Autumn storms may mobilize Hg into these pools; concentrations of $\mathrm{DOC}$ and $\mathrm{THg}$ were high for all but pool B1 in the early October, pool-refilling storm.

Our data reflect the expected trends in chemical covariates with $\mathrm{Hg}$ : high concentrations of DOC, low $\mathrm{pH}$, and low ANC correlated with elevated $\mathrm{THg}$ concentrations in biota, including lake fish (Chen et al. 2005, Driscoll et al. 2007). 
We found that pools with high DOC and low $\mathrm{pH}$ had greater $\mathrm{THg}$ in water, greater dissolved $\mathrm{Al}$ in water (Palmer et al. 2005), and greater $\mathrm{THg}$ concentrations in Wood Frogs. Greatest total dissolved Al concentrations were measured in U2 in April $(806 \mu \mathrm{g} / \mathrm{L}, \mathrm{pH}=4.17)$, exceeding the $\mathrm{LC}_{50}(750 \mu \mathrm{g} / \mathrm{L}$ at $\mathrm{pH}=4.8$; Sparling et al. 1997) for Wood Frogs. LC $_{50}$ values may not be predictive of Al toxicity, which is affected by water chemistry.

\section{Implications for future research}

The spatial variation of $\mathrm{Hg}$ concentrations among pools and within-pool characteristics suggest that local conditions are important in determining THg accumulation (Grigal 2002, 2003; Rencz et al. 2003, Unrine et al. 2005). Although pool water demonstrated predicted patterns of $\mathrm{THg}$ (greater in softwood-embedded sites with high DOC and low $\mathrm{pH}$ ), $\mathrm{THg}$ measured in other components (sediment, litter, Wood Frogs) did not exhibit this pattern. Pools selected for future study should include replicates of the variety of local pool conditions, such as sediment type, forest species dominance, and hydroperiod range including pools that dry before metamorphosis, those that hold water through metamorphosis in years with average precipitation, and pools that dry only occasionally, to reveal the role of these conditions in determining $\mathrm{THg}$ and $\mathrm{MeHg}$ dynamics throughout the pool drawdown and refilling cycle. The proportion of accumulated $\mathrm{THg}$ that is $\mathrm{MeHg}$ in Wood Frogs near metamorphosis in our study pools was in the range of that reported by Bank et al. (2005) for 2-3 year old Green Frog and Bullfrog tadpoles that had not yet metamorphosed. It is unknown when the Green Frog and Bullfrog tadpoles accumulated the $\mathrm{Hg}$ in their tissues; however, the $\mathrm{THg}$ and $\mathrm{MeHg}$ detected in our Wood Frog tadpoles accumulated during the 6-8 weeks between egglaying and metamorphosis, indicating accumulation was quite rapid. Future research should quantify the ratio of $\mathrm{THg}$ to $\mathrm{MeHg}$ in developing embryos, tadpoles, and juveniles emigrating from natal ponds to better understand transport of this contaminant from seasonal pools into the surrounding environment and potential for uptake into the terrestrial food web.

\section{Acknowledgments}

We wish to thank B. Connery, D. Manski, and Acadia National Park for permission to conduct this research and access study sites. C. Devoy provided guidance for sample collection and assistance with sample analysis. This research was financially supported by the University of Maine, the Maine Department of Inland Fisheries and Wildlife, the Maine Outdoor Heritage Fund, the US Geological Survey S.O. Conte Anadromous Fish Research Laboratory, Maine Field Office, and the US Geological Survey, Maine Cooperative Fish and Wildlife Research Unit. A Fitz Eugene Dixon Fellowship through the Schoodic Education and Research Center Institute provided support for S. Nelson. Mention of trademarks or commercial products does not imply endorsement by the US government. This research was conducted under protocol (A2008-0302) approved by the University of Maine's Animal Care and Use Committee. The manuscript was improved by reviews and suggestions from A. Amirbahman, 
R. Baldwin, and two anonymous reviewers. This is University of Maine Agricultural and Forest Experiment Station Publication Number 3299.

\section{Literature Cited}

Amirbahman, A., P.L. Ruck, I.J. Fernandez, T.A. Haines, and J.S. Kahl. 2004. The effect of fire on mercury cycling in the soils of forested watersheds: Acadia National Park, Maine, USA. Water, Soil, and Air Pollution 152:313-331.

ASTM D 2974. 2007. Standard test methods for moisture, ash, and organic matter of peat and organic soils. ASTM International, West Conshohocken, PA.

Bailey, R.G., P.E. Avers, T. King, and W.H. McNab. 1994. Ecoregions and subregions of the United States (map). 1:7,500,000, with supplementary table of map unit descriptions, compiled and edited by W.H. McNab and R.G. Bailey. USDA Forest Service, Washington, DC.

Baldwin, R., and A.J.K. Calhoun. 2002. Differential predation on ambystomatid egg masses by Rana sylvatica. Herpetological Reviews 33:44-45.

Bank, M.S., C.S. Loftin, and R.E. Jung. 2005. Effects of watershed heterogeneity on mercury bioaccumulation in Two-lined Salamanders from the northeastern United States. Ecotoxicology 14:181-191.

Bank, M.S., J.R. Burgess, D.C. Evers, and C.S. Loftin. 2007a. Mercury contamination of biota from Acadia National Park: A review. Environmental Monitoring and Assessment 139:105-115.

Bank, M.S., J. Crocker, B. Connery, and A. Amirbahman. 2007b. Mercury bioaccumulation in Green Frog and Bullfrog tadpoles from Acadia National Park, Maine, USA. Environmental Toxicology and Chemistry 26:118-125.

Benoit, J.M., C.C. Gilmour, A. Heyes, R.P. Mason, and C.L. Miller. 2002. Geochemical and biological controls over methylmercury production and degradation in aquatic ecosystems. Pp. 262-297, In Y. Cai and O.C. Braids (Eds.). Biogeochemistry of Environmentally Important Trace Metals. ACS Symposium Series, Vol. 835, University of Maryland Center for Environmental Science, Solomons, MD.

Bergeron, C.M., C.M. Bodinof, J.M. Unrine, and W.A. Hopkins. 2010a. Bioaccumulation and maternal transfer of mercury and selenium in amphibians. Environmental toxicology and chemistry 29:989-997.

Bergeron, C.M., C.M. Bodinof, J.M. Unrine, and W.A. Hopkins. 2010b. Mercury accumulation along a contamination gradient and nondestructive indices of bioaccumulation in amphibians. Environmental Toxicology and Chemistry 29:980-988.

Berven, K.A. 2009. Density dependence in the terrestrial stage of Wood Frogs: Evidence from a 21-year population study. Copeia 2:328-338.

Birge, W.J., J.A. Black, A.G. Westerman, and J.E. Hudson. 1979. The effects of mercury on reproduction of fish and amphibians. Pp. 629-655, In J.O. Nriagu (Ed.). The Biogeochemistry of Mercury in the Environment. Elsevier/North-Holland Biomedical Press, New York, NY.

Boone, M., and B. Pauli. 2008. Contamination in the food webs of vernal pools. Pp. 213-232, In A.J.K. Calhoun and P.M. deMaynadier (Eds.). Vernal Pools: Ecology and Conservation of Seasonal Wetlands in Northeastern North America. CRC Press, New York, NY.

Bridges, C., E. Little, D. Gardiner, J. Petty, and J. Huckins. 2004. Assessing the toxicity and teratogenicity of pond water in north-central Minnesota to amphibians. Environmental Science and Pollution Research 11:233-239. 
Britson, C.A., and S.T. Threlkeld. 1998. Abundance, metamorphosis, developmental, and behavioral abnormalities in Hyla chrysoscelis tadpoles following exposure to three agrichemicals and methyl mercury in outdoor mesocosms. Bulletin of Environmental Contamination and Toxicology 61:154-161.

Calhoun, A.J.K., and P.G. deMaynadier (Eds.). 2008. Science and Conservation of Vernal Pools in Northeastern North America. CRC Press, Boca Rotan, FL. 376 pp.

Calhoun, A., J. Cormier, R. Owen, Jr., C. Roman, A. O'Connell, and R. Tiner. 1994. The wetlands of Acadia National Park and vicinity. US Fish and Wildlife Service, National Wetlands Inventory, Newton Corner, MA. 108 pp.

Chapman, C.A. 1970. The Geology of Acadia National Park. Chatham Press, Old Greenwich, CT. 127 pp.

Chen, C.Y., R.S. Stemberger, N.C. Kamman, B.M. Mayes, and C.L. Folt. 2005. Patterns of $\mathrm{Hg}$ bioaccumulation and transfer in aquatic food webs across multi-lake studies in the Northeast US. Ecotoxicology 14:135-147.

Colburn, E.A. 2004. Vernal Pools: Natural History and Conservation. The McDonald and Woodward Publishing Company, Blacksburg, VA. 426 pp.

Cummins, C.P. 1986. Effects of aluminium and low $\mathrm{pH}$ on growth and development in Rana temporaria tadpoles. Oecologia 69:248-252.

Cunningham, J., A.J.K. Calhoun, and W.E. Glanz. 2007. Pond-breeding amphibian species richness and breeding habitat selection in a Beaver-modified landscape. Journal Wildlife Management 71:2517-2526.

Demers, J.D., C.T. Driscoll, T.J. Fahey, and J.B. Yavitt. 2007. Mercury cycling in litter and soil in different forest types in the Adirondack region, New York, USA. Ecological Applications 17:1341-1351.

Driscoll, C., Jr., J. Baker, J. Bisgoni, Jr., and C. Schofield. 1980. Aluminum speciation and its effect on fish in dilute acidified waters. Nature 284:161-163.

Driscoll, C.T., H. Young-Ji, C.Y. Chen, D.C. Evers, K.F. Lambert, T.M. Holsen, N.C. Kamman, and R.K. Munson. 2007. Mercury contamination in forest and freshwater ecosystems in the northeastern United States. Bioscience 57:17-28.

Fleck, J.A. 1999. Mercury transport through northern forested watersheds: Dissolved and particulate pathways. M.Sc. Thesis. University of Minnesota, St. Paul, MN.

Gahl, M.K., and A.J.K. Calhoun. 2010. The role of multiple stressors in ranavirus-caused amphibian mortalities in Acadia National Park wetlands. Canadian Journal of Zoology 88:108-121.

Gibbons, J.W., C.T. Winne, D.E. Scott, J.D. Willson, X. Glaudas, K.M. Andrews, B.D. Todd, L.A. Fedewa, L. Wilkinson, R.N. Tsaliagos, S.J. Harper, J.L. Greene, T. Tuberville, B.S. Metts, M.E. Dorcas, J.P. Nestor, C.A. Young, T. Akre, R.N. Reed, K.A. Buhlman, J. Norman, D.A. Croshaw, C. Hagen, and B.B. Rothermel. 2006. Remarkable amphibian biomass and abundance in an isolated wetland: Implications for wetland conservation. Conservation Biology 20:1457-65.

Gilman, R.A., C.A. Chapman, T.V. Lowell, and H.W. Borns, Jr. 1988. The geology of Mount Desert Island: A visitor's guide to the geology of Acadia National Park. Maine Geological Survey, Department of Conservation, Augusta, ME. 50 pp.

Gosner, K.L. 1960. A simplified table for staging anuran embryos and larvae with notes on identification. Herpetologica 16:183-190.

Grigal, D.F. 2002. Inputs and outputs of mercury from terrestrial watersheds: A review. Environmental Review 10:1-39. 
Grigal, D.F. 2003. Mercury sequestration in forests and peatlands: A review. Journal of Environmental Quality 32:393-405.

Grigal, D.F., R.K. Kolka, J.A. Fleck, and E.A. Nater. 2000. Mercury budget of an uplandpeatland watershed. Biogeochemistry 50:95-109.

Hillman, D.C., J. Potter, and S. Simon. 1986. Analytical methods for the National Surface Water Survey, Eastern Lake Survey. EPA/600/4-86/009,US Environmental Protection Agency, Las Vegas, NV.

Hurley, J.P., S.E. Cowell, M.M. Shafer, and P.E. Hughes. 1998. Tributary loading of mercury to Lake Michigan: Importance of seasonal events and phase partitioning. Science of the Total Environment 213:129-137.

Johnson, K.B., T.A. Haines, J.S. Kahl, S.A. Norton, A. Amirbahman, and K.D. Sheehan. 2007. Controls on mercury and methylmercury deposition for two watersheds in Acadia National Park, Maine. Environmental Monitoring and Assessment 126:55-67. Kahl, J.S., J.L. Stoddard, S.G. Haeuber, S.G. Paulsen, F.A. Deviney, J.R. Webb, D.R. DeWalle, W. Sharpe, C.T. Driscoll, A.T. Herlihy, J.H. Kellogg, P.S. Murdoch, K. Roy, K.E. Webster, and N.S. Urquhart. 2004. Have US surface waters responded to the 1990 Clean Air Act Amendments? Environmental Science and Technology 38:484A-490A.

Kahl, S.J., S.J. Nelson, I. Fernandez, T. Haines, S. Norton, G.B. Wiersma, G. Jacobson, A. Amirbahman, K. Johnson, M. Schauffler, L. Rustad, K. Tonnessen, R. Lent, M. Bank, J. Elvir, J. Eckhoff, H. Caron, P. Ruck, J. Parker, J. Campbell, D. Manski, R. Breen, K. Sheehan, and A. Grygo. 2007. Watershed nitrogen and mercury geochemical fluxes integrate landscape factors in long-term research watersheds at Acadia National Park, Maine, USA. Environmental Monitoring and Assessment 126:9-25.

Kolka, R.K., E.A. Nater, D.F. Grigal, and E.S. Verry. 1999. Atmospheric inputs of mercury and organic carbon into a forested upland/bog watershed. Water, Air, and Soil Pollution 113:273-294.

Kolozsvary, M.B. 2003. Hydroperiod of wetlands and reproduction in Wood Frogs (Rana sylvatica) and Spotted Salamanders (Ambystoma maculatum). Ph.D. Dissertation. University of Maine, Orono, ME.

Krabbenhoft, D.P., J.M. Benoit, C.L. Babiarz, J.P. Hurley, and A.W. Andren. 1995. Mercury cycling in the Allequash Creek watershed, northern Wisconsin. Water, Air, and Soil Pollution 80:425-433.

Lee, Y.-H., G.C. Borg, A. Iverfeldt, and H. Hultberg. 1994. Fluxes and turnover of methylmercury: Mercury pools in forest soils. Pp. 329-342, In C.J. Watras and J.W. Huckabee (Eds.). Proceedings of the International Conference on Mercury as a Global Pollutant. Monterey, CA. 31 May-4 June 1992. Electric Power Research Insttitute, Palo Alto, CA.

Lindberg, S.E. 1996. Forests and the global biogeochemical cycle of mercury. Pp. 359-380, In W. Baeyens, R. Ebinghaus, and O. Vasiliev (Eds.). Global and Regional Mercury Cycles: Sources, Fluxes, and Mass Balances. NATO-ASI-Series Volume 21, Kluwer Academic Publishers, Dordrecht, The Netherlands.

Longcore, J.R., T.A. Haines, and W.A. Halteman. 2007. Mercury in Tree Swallow food, eggs, bodies, and feathers at Acadia National Park, Maine, and an EPA superfund site, Ayer, Massachusetts. Environmental Monitoring and Assessment 126:129-143.

Lorey, P., and C.T. Driscoll. 1999. Historical trends of mercury deposition to Adirondack lakes. Environmental Science and Technology 33:718-722. 
Miller, E., A. Vanarsdale, G. Keeler, A. Chalmers, L. Poissant, N. Kamman, and R. Brulotte. 2005. Estimation and mapping of wet and dry mercury deposition across northeastern North America. Ecotoxicology 14:53-70.

Mitchell, J.C., P.W.C. Paton, and C.J. Raithel. 2008. The importance of vernal pools to birds, reptiles, and mammals. Pp 169-192, In A.J.K. Calhoun and P.M. deMaynadier (Eds.). Vernal Pools: Ecology and Conservation of Seasonal Wetlands in Northeastern North America. CRC Press, New York, NY.

Navratil, T., S.A. Norton, I.J. Fernandez, and S.J. Nelson. 2010. Twenty-year inter-annual trends and seasonal variations in precipitation and stream-water chemistry at the Bear Brook Watershed in Maine, USA. Environmental Monitoring and Assessment Online First: DOI 10.1007/s10661-010-1527-z.

Nelson, S.J., K.B. Johnson, J.S. Kahl, T.A. Haines, and I.J. Fernandez. 2007. Mass balances of mercury and nitrogen in burned and unburned forested watersheds at Acadia National Park, Maine, USA. Environment Monitoring and Assessment 126:69-80.

Nelson, S.J., K.B. Johnson, K.C. Weathers, C.S. Loftin, I.J. Fernandez, J.S. Kahl, and D.P. Krabbenhoft. 2008. A comparison of winter mercury accumulation at forested and no-canopy sites measured with different snow-sampling techniques. Applied Geochemistry 23:384-398.

Palmer, S.M., B.I. Wellington, C.E. Johnson, and C.T. Driscoll. 2005. Landscape influences on aluminum and dissolved organic carbon in streams draining the Hubbard Brook valley, New Hampshire, USA. Hydrological Processes 19:1751-1769.

Peckenham, J.M., J.S. Kahl, S.J. Nelson, K.B. Johnson and T.A. Haines. 2007. Landscape controls on mercury in streamwater at Acadia National Park, USA. Environmental Monitoring and Assessment 126:97-104.

Petranka, J.W., M.E. Hopey, B.T. Jennings, S.D. Baird, and A.J. Boone. 1994. Breeding habitat segregation of Wood Frogs and American Toads: The role of interspecific tadpole predation and adult choice. Copeia 1994:691-697.

Rea, A.W., G.J. Keeler, and T. Scherbatskoy. 1996. The deposition of mercury in throughfall and litterfall in the Lake Champlain watershed: A short-term study. Atmospheric Environment 30:3257-3263.

Rea, A.W., S.E. Lindberg, and G.J. Keeler. 2001. Dry deposition and foliar leaching of mercury and selected trace elements in deciduous forest throughfall. Atmospheric Environment 35:3453-3462.

Rencz, A.N., N.J. Driscoll, G.E.M. Hall, T. Peron, K.Telmer, and N.M. Burgess. 2003. Spatial variation and correlations of mercury levels in the terrestrial and aquatic components of a wetland dominated ecosystem: Kejimkujik Park, Nova Scotia, Canada. Water, Soil, and Air Pollution 143:271-288.

Schauffler, M., S.J. Nelson, J.S. Kahl, G.L. Jacobson, Jr., T.A. Haines, W.A. Patterson III, and K.B. Johnson. 2007. Paleoecological assessment of watershed history in PRIMENet watersheds at Acadia National Park, USA. Environmental Monitoring and Assessment 126:39-53.

Scherbatskoy, T., J.B. Shanley, and G.J. Keeler. 1998. Factors controlling mercury transport in an upland forested catchment. Water, Air, and Soil Pollution 105:427-438.

Schluter, K., H.M. Seip, and J. Alstad. 1995. Mercury translocation in and evaporation from soil. II. Evaporation of mercury from podzolized soil profiles treated with $\mathrm{HgCl}_{2}$ and $\mathrm{CH}_{3} \mathrm{HgCl}$. Journal of Soil Contamination 4:269-298. 
Schuster, P., J. Shanley, M. Marvin-Dipasquale, M. Reddy, G. Aiken, D. Roth, H. Taylor, D. Krabbenhoft, and J. DeWild. 2008. Mercury and organic carbon dynamics during runoff episodes from a northeastern USA watershed. Water, Air, and Soil Pollution 187:89-108.

Shanley, J.B., P.F. Schuster, M.M. Reddy, D.A. Roth, H.E. Taylor, and G.R. Aiken. 2002. Mercury on the move during snowmelt in Vermont. EOS Transactions of the American Geophysical Union 83:45, 47-48.

Shanley, J.B., N.C. Kamman, T.A. Clair, and A. Chalmers. 2005. Physical controls on total and methylmercury concentrations in streams and lakes of the northeastern USA. Ecotoxicology 14:125-134.

Sheehan, K.D., I.J. Fernandez, J.S. Kahl, and A. Amirbahman. 2006. Litterfall mercury in two forested watersheds at Acadia National Park, Maine, USA. Water, Soil, and Air Pollution 170:249-265.

Sours, G.N., J.W. Petranka, and S.F. Fox. 2007. Intraguild predation and competition mediate stage-structured interactions between Wood Frog (Rana sylvatica) and Upland Chorus Frog (Pseudacris feriarum) larvae. Copeia 2007:131-139.

Sparling, D.W., T.P. Lowe, and P.G.C. Campbell. 1997. Ecotoxicology of aluminum to fish and wildlife. Pp. 47-68, In R.A. Yokel and M.S. Golub (Eds.). Research Issues in Aluminum Toxicity. Taylor and Francis, Washington, DC.

St. Louis, V.L, J.W.M. Rudd, C.A. Kelly, K.G. Beaty, N.S. Bloom, and R.J. Flett. 1994. The importance of wetlands as sources of methyl mercury to boreal forest ecosystems. Canadian Journal of Fisheries and Aquatic Sciences 51:1065-1076.

Terhivuo, J., M. Lodenius, P. Nuorteva, and E. Tulisalo.1984. Mercury content of Common Frogs (Rana temporaria L.) and Common Toads (Bufo bufo L.) collected in southern Finland. Annales Zoologici Fennici 21:41-44.

Unrine, J.M., C.H. Jagoe, W.A. Hopkins, and H.A. Brant. 2004. Adverse effects of ecologically relevant dietary mercury exposure in Southern Leopard Frog (Rana sphenocephala) larvae. Environmental Toxicology and Chemistry 23:2964-2970.

Unrine, J.M., C.H. Jagoe, A.C. Briton, H.A. Brant, and N.T. Garvin. 2005. Dietary mercury exposure and bioaccumulation in amphibian larvae inhabiting Carolina bay wetlands. Environmental Pollution 135:245-253.

Unrine, J.M., W.A. Hopkins, B.P. Jackson, and C.S. Romanek. 2007. Bioaccumulation of trace elements in omnivorous amphibian larvae: Implications for amphibian health and contaminant transport. Environmental Pollution 149:182-192.

US Environmental Protection Agency (US EPA). 1994. Method 3051 A: Microwaveassisted acid digestion of sediments, sludges, soils, and oils. Office of Science and Technology, Engineering and Analysis Division (4303), Washington, DC.

US EPA. 2002. Method 1631, Revision E: Mercury in Water by Oxidation, Purge and Trap, and Cold Vapor Atomic Fluorescence Spectrometry, EPA-821-R-02-019. Office of Water, Washington, DC.

Wake, D.B., and V.T. Vredenburg. 2008. Are we in the midst of the sixth mass extinction? A view from the world of amphibians. Proceedings of the National Academy of Science USA 105:11466-11473.

Westfeld, M., R.I. Ashman, H.I. Baldwin, R.P. Holdsworth, R.S. Johnson, J.H. Lambert, H.J. Schultz, L. Swain, and M. Standish. 1956. Natural forest vegetation zones of New England. Journal of Forestry 54:332-338. 
Windmiller, B.W. 1996. The pond, the forest, and the city: Spotted Salamander ecology and conservation in a human-dominated landscape. Ph.D. Dissertation. Tufts University, Medford, MA.

Windmiller, B. and A.J.K. Calhoun. 2008. Conserving vernal pool wildlife in urbanizing landscapes Pp. 233-252, In A.J.K. Calhoun and P.G. deMaynadier (Eds.). Science and Conservation of Vernal Pools in Northeastern North America. CRC Press, Boca Rotan, FL. 376 pp. 